\title{
Use of human-made nesting structures by wild bees in an urban environment
}

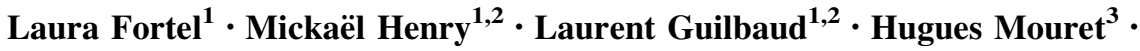 \\ Bernard E. Vaissière ${ }^{1,2}$
}

Received: 25 October 2015/Accepted: 7 March 2016/Published online: 16 March 2016

(c) The Author(s) 2016. This article is published with open access at Springerlink.com

\begin{abstract}
Most bees display an array of strategies for building their nests, and the availability of nesting resources plays a significant role in organizing bee communities. Although urbanization can cause local species extinction, many bee species persist in urbanized areas. We studied the response of a bee community to winter-installed humanmade nesting structures (bee hotels and soil squares, i.e. $0.5 \mathrm{~m}$ deep holes filled with soil) in urbanized sites. We investigated the colonization pattern of these structures over two consecutive years to evaluate the effect of age and the type of substrates (e.g. logs, stems) provided on colonization. Overall, we collected 54 species. In the hotels, two gregarious species, Osmia bicornis L. and O. cornuta Latr. dominated the community (over $87 \%$ of the data). Over 2 years, the age of the soil squares did not affect their level of colonization and the same was true for the hotels with respect to $O$. bicornis and 'other species'. However, O. cornuta occurred less often and raised fewer descendants in 1-year old hotels than in new ones. Bee nesting was not affected by the soil texture and, among above-ground nesting bees, only
\end{abstract}

This work is dedicated in memoriam of Robert Fonfria.

Electronic supplementary material The online version of this article (doi:10.1007/s10841-016-9857-y) contains supplementary material, which is available to authorized users.

Laura Fortel

laura.fortel@gmail.com

1 UR 406 Abeilles et Environnement, INRA - Site Agroparc Domaine Saint Paul, 84914 Avignon Cedex 9, France

2 UMT Protection des Abeilles dans l'Environnement, 84914 Avignon, France

3 Arthropologia, Ecocentre du Lyonnais, La Tour de Salvagny, France
O. bicornis showed a preference for some substrates, namely Acer sp. and Catalpa sp. In a context of increasing urbanization and declining bee populations, much attention has focused upon improving the floral resources available for bees, while little effort has been paid to nesting resources. Our results indicate that, in addition to floral availability, nesting resources should be taken into account in the development of urban green areas to promote a diverse bee community.

Keywords Wild bees - Nesting resource availability . Nest-site fidelity · Phylopatry · Nest-site selection · Substrate quality $\cdot$ Human-made nesting structures . Urban area

\section{Introduction}

Bees (Hymenoptera: Anthophila) display an array of strategies regarding the habitat they nest in, the type of substrate they use, and the materials they require for their nest construction (Potts et al. 2005). Bees can be classified into three guilds on the basis of their nesting habits (O'Toole and Raw 2004): ground or above-ground nesting and cleptoparasites. Ground nesting bees, represent the majority of bee species and dominate in many open habitats (O'Toole and Raw 2004; Michener 2007). Ground nesting female bees excavate subterranean tunnels terminated by chambers or cells, which they provision with a mass of pollen and nectar (Cane 1991). All species of Andrenidae and Melittidae are ground-nesting, as are most species of Halictidae and Colletidae (Michener 2007). The above-ground nesting guild, which is dominated by Megachildae and Apidae families, nest either in pre-existing holes (Roubik 1989; Michener 2007) or dig their 
own cavities in firm substrate (e.g. pithy plant stems or soft wood; Roubik 1989; Michener 2007). Some species, called gregarious nesters [e.g. Osmia bicornis Linné (Fliszkiewicz et al. 2013) or Andrena vaga Panzer (Rezkova et al. 2011)], breed individually like solitary bees, but nest close to conspecifics, sometimes at high densities over a limited area. Finally, cleptoparasitic bees do not construct nests, but instead lay their eggs in the nests of other bees so that these eggs can hatch and steal the food and the nest, and are therefore referred to as cuckoo bees (Wcislo 1987).

Little is known about particular biotic and abiotic factors influencing nesting success or nesting site selection by different bee species (Cane 2008; Sardiñas and Kremen 2014). A range of studies point out that within-site characteristics, such as exposed bare ground (e.g. Potts et al. 2005), litter cover (e.g. Grundel et al. 2010), soil texture (e.g. Cane 1991), soil compaction (e.g. Wuellner 1999; Sardiñas and Kremen 2014), soil moisture (e.g. Wuellner 1999), soil slope (e.g. Potts and Willmer 1997; Sardiñas and Kremen 2014), spatial distribution (e.g. Sardiñas and Kremen 2014), or number of potential nesting cavities (cracks or holes in the ground; e.g. Potts et al. 2005), were determinants in nest selection of ground-nesting bees. Above-ground nesting bees nest in different types of substrate such as wood, hollow plant stems (e.g., Phyllostachys sp., Phragmites sp., or Arundo sp.), pithy plant stems (e.g., Buddleja sp., Rubus sp., or Ailanthus sp.), or any other sort of cavities (e.g., in adobe walls, abandoned insect burrows, bird nests or even snail shells) (Amiet et al. 1999; Pouvreau 2004; Michener 2007). The diameter and height of preexisting holes plays an important role in nesting site selection (e.g. Scott 1994). Bees also need different materials to build their nest. For example, Osmia spp., use mud to separate cells and close their nest and Heriades truncorum uses some resin (Amiet et al. 2004; Michener 2007).

Two studies provide quantitative evidence showing that nesting resources have an important role in structuring bee communities (Potts et al. 2003) or key guilds within communities (Cane 1991). Potts et al. (2003) examined 14 habitat characteristics as predictors of bee community structure. Floral characters were the primary determinants, but still $5 \%$ of the bee community structure was explained by the diversity of nesting resources available, and this went up to $10 \%$ when only dominant bee species were considered. These findings demonstrate that the availability of diverse nesting resources plays a significant role in organizing bee communities. Habitats may not be uniform in their ability to support populations of bees in relation to the nesting sites available (Grundel et al. 2010). Urbanization is one of the principal causes of species extirpation, threatening species by the direct destruction of their habitat and also indirectly by removing their resources (Czech et al.
2000; Zanette et al. 2005; Hennig and Ghazoul 2012). In the course of urbanization, impervious surface modifies habitats (Marzluff and Ewing 2001), and usually, the open green spaces left in urban areas are often parks, gardens, brownfields, train corridors, and recreational areas (Müller et al. 2013). The soils of these remaining areas are modified and their management changes the food and nesting resources available to bees compared to more natural environment (Cane et al. 2006; Müller and Werner 2010; Hennig and Ghazoul 2012). Thus urbanization often degrades nesting habitat, especially for ground-nesting bees, by transforming vegetation composition and structure (e.g. scrub converted to grass lawns, washes confined to concrete flumes) and altering surface soils through compaction (Cane et al. 2006). Cutting dead trees or removing fallen trees and brush piles in urban areas make these potential nesting sites no longer available as substrates for bees to nest in (SteffanDewenter and Leschke 2003; McFrederick and LeBuhn 2006). Changes due to urban management are not as adverse for above-ground nesting bee species as for groundnesting species, because cavities in wood and other substrates also occur in the houses, fences, and introduced woody landscape vegetation (Cane et al. 2006). Nevertheless, cutting dead trees or removing fallen trees and brush piles in urban areas removes potential nesting sites for bees (Steffan-Dewenter and Leschke 2003; McFrederick and LeBuhn 2006). Also, landscaping with horticultural taxa (Garbuzov and Ratnieks 2014) and the spread of invasive plants (Meekins and McCarthy 2001) leads to a loss of native vegetation. Indeed, oligolectic bee species (i.e. depending exclusively on one or a few plant taxa for pollen food) are more rare in urban areas than polylectic bee species (i.e. capable of gathering pollen from a broad array of plant species) (Fetridge et al. 2008; Banaszak-Cibicka and Żmihorski 2012) because the latter are capable of gathering pollen from exotic ornamental plants (Frankie et al. 2005). Yet, despite all this, many bee species can persist in urbanized areas (McFrederick and LeBuhn 2006; Banaszak-Cibicka and Żmihorski 2012; Fortel et al. 2014).

Ground-nesting bees can be assessed using tent traps that cover a portion of the ground, known as emergence traps (etraps), and bee-hotels (usually made from bundled plant stems or holes drilled in wood) can artificially aggregate nesting sites above densities naturally available for aboveground nesting bees (Krombein and Wasps 1967). But these methods have rarely been used (Kim et al. 2006; MacIvor and Packer 2015). Standard bee collection techniques are pan-traps (colored bowls filled with soapy water) and hand netting at flowers (Westphal et al. 2008), but these methods do not directly capture bees from their nests. Therefore, the ability of habitat to support nesting is often inferred from the presence of bee species from specific nesting guilds (e.g. 
Morandin and Kremen 2013), assuming that bees found at a location must be nesting somewhere within a distance corresponding to their foraging range (Lonsdorf et al. 2009), or the presence of potential nesting resources (e.g. Potts et al. 2005; Grundel et al. 2010), assuming that the availability of nesting resources affects the ability of native bees to nest in a given area.

Since nesting availability plays a role in structuring bee communities (Cane 1991; Potts et al. 2003), we reasoned that providing human-made nesting structures in the urban environment may be a useful tool to study bee communities and possibly locally sustain and increase the population of a range of species. In this context, we studied, over a 2-year period, how human-made nesting structures (bee hotels and soil squares) can be useful for the bee community in an urban environment. Our hypotheses were that (1) the abundance of ground and above-ground nesting bees would increase in the bee hotels and the soil squares, respectively, between the first and the second year of installation, (2) the age of nesting structures would have a positive effect on abundance and diversity of nesting bee species; (3) some substrates (i.e. logs, stems, or soil) would be preferred to others by bees for building their nests.

\section{Materials and methods}

\section{Study sites}

The study was conducted in the urban community of Grand Lyon, France, which includes 58 towns around Lyon $\left(45^{\circ} 46^{\prime} \mathrm{N}, 4^{\circ} 50^{\prime} \mathrm{E}\right)$ and covers an area of $516 \mathrm{~km}^{2}$ with approximately 1.3 million inhabitants (Insee Rhône-Alpes 2013). The climate of Lyon is at the temperate-Mediterranean interface. The 30-year annual average temperature is $12{ }^{\circ} \mathrm{C}$ with a minimum of $3{ }^{\circ} \mathrm{C}$ in January and a maximum of $21{ }^{\circ} \mathrm{C}$ in July (InfoClimat 2011).

The sites studied here are a subset from those studied in Fortel et al. (2014). We selected 16 sites with more than $30 \%$ of impervious surface (i.e. buildings, roads and industrial areas) over a two $\mathrm{km}$ radius. Eight sites had a proportion of impervious surface between 30 and $70 \%$ (periurban sites), and the remaining eight had $>70 \%$ of impervious surface (urban sites). Each site was located in green areas, parks or gardens. All sites were separated by less than two $\mathrm{km}$ from each other to prevent overlapping of bee communities (Zurbuchen et al. 2010b). Indeed, wild bees cover relatively short foraging or commuting flights, most often one to several hundred meters long (Zurbuchen et al. 2010a, b), and the capability to cover long distances and to use resources on a large spatial scale mostly applies to larger bees (e.g. genera Bombus or Xylocopa; Greenleaf et al. 2007).

\section{Human-made nesting structures}

Soil squares and bee hotels were built to study the use and preference of wild bees with respect to each artificial nest type (Fig. 1).

Each soil square consisted of a $1 \mathrm{~m}^{2}$ wooden frame surrounding a $0.5 \mathrm{~m}$ deep hole with a layer of stones at the bottom to provide drainage. The soil squares were located on flat ground and in open areas as much as possible so as to be exposed to direct sun as soil exposition is important for nest site selection (Wuellner 1999; Potts et al. 2005). Squares were dug and filled with the local soil alone (3 control squares) or with this soil mixed with $1 / 4,1 / 3$ or $1 / 2$ of clay or sand. We then had three groups of soil squares: one group with one soil square with $100 \%$ of local site (the one excavated from the holes), one with $3 / 4$ of local soil and 1/4 of sand and one with 3/4 of local soil and 1/4 of clay, a second group with one soil square with $100 \%$ of local site (the one excavated from the holes), one with $2 / 3$ of local soil and $1 / 3$ of sand and one with $2 / 3$ of local soil and 1/3 of clay and a third group with one soil square with $100 \%$ of local site (the one excavated from the holes), one with $1 / 2$ of local soil and $1 / 2$ of sand and one with $1 / 2$ of local soil and $1 / 2$ of clay. Plant growth within soil squares was removed manually on a monthly basis to maintain areas of bare soil that are essential for soil-nesting bees (Potts et al. 2005). This frequency was also chosen to minimize damage to the potential nests already built. Squares were covered with a frame of chicken wire so that domestic animals would not damage the device or disturb the nesting activity.

Bee hotels were set-up near the soil squares. At each site, we built three hotels oriented in different directions (e.g. north/west-south/east). They consisted of $4 \times 2 \mathrm{~m}$ wooden structures with 9 compartments measuring $0.8 \mathrm{~m}$ wide $\times 0.45 \mathrm{~m}$ high $\times 0.5 \mathrm{~m}$ deep and filled with various types of nesting materials known to be used by above-ground nesting bees, such as logs drilled with holes, hollow or pithy stems of different species. Overall four compartments contained logs or stems while the other ones contained adobe. We used, eight species of logs (Acer sp., Ailanthus sp., Fraxinus sp., Platanus sp., Populus sp., Prunus sp., Robinia sp, and Tilia sp.), three of hollow stems (Arundo sp., Phragmites sp, and Phyllostachys sp.), and four of pithy stems (Ailanthus sp., Catalpa sp., Buddleja sp, and Sambucus sp.). Inasmuch as possible, we used materials available where the hotels were located (remnants from tree pruning and hedge trimmings). The logs were drilled with electric drills on both ends with holes ranging from 4 to $12 \mathrm{~mm}$ diameter and their depth was $0.20 \mathrm{~m}$ to avoid drilling throughout. Every compartment was completely filled in order to have a large and potentially nonlimiting number of cavities.

At each site, nine soil squares and three bee hotels were built. Eight sites (four periurban and four urban, selected at 


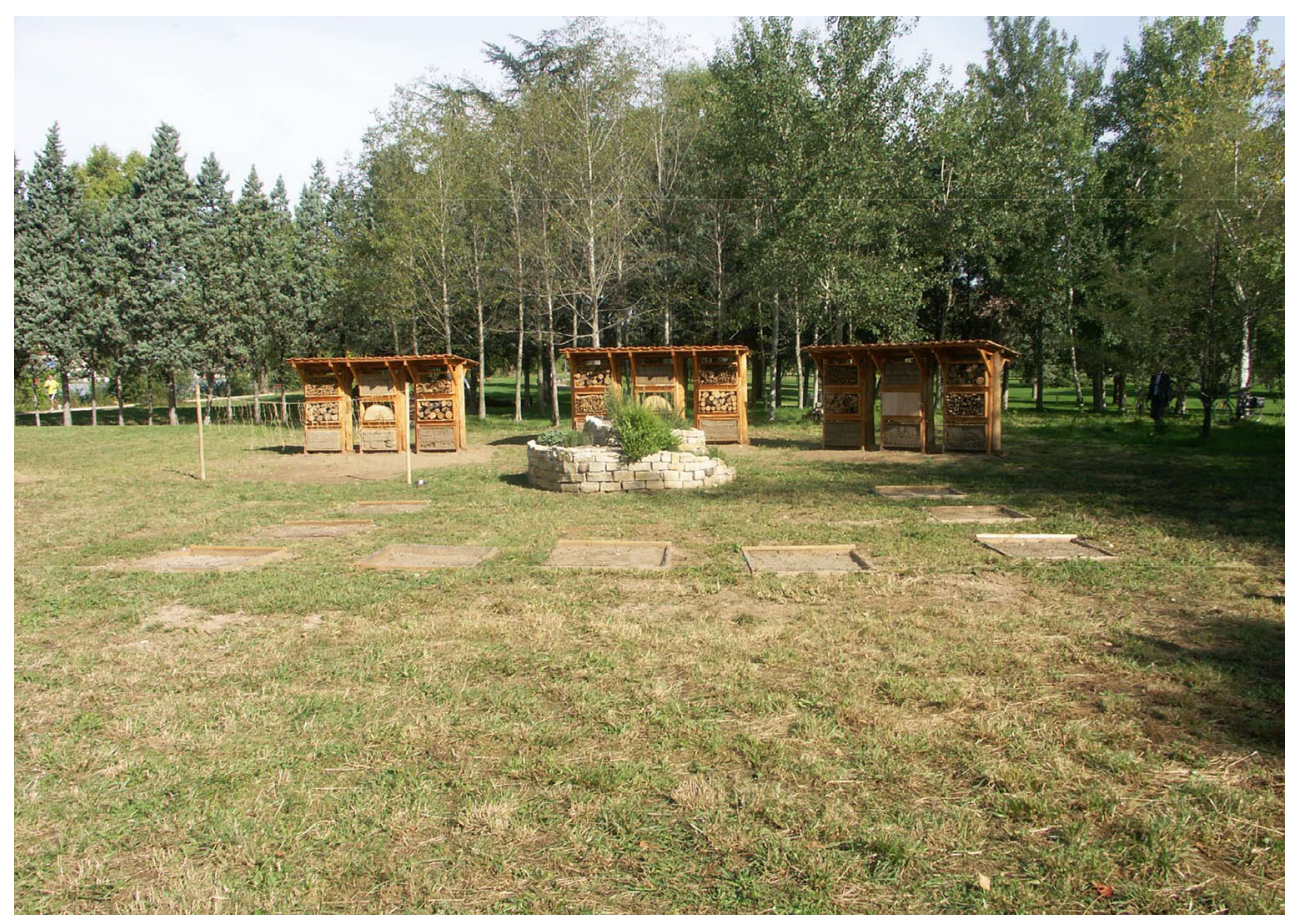

Fig. 1 Human-made nesting structures set in the winter of 2010/2011 in Sainte-Foy-Lès Lyon, France. A nine-compartment bee hotel is on the left while three soil squares are visible on the right

random within the eight periurban sites and the eight urban sites respectively) were set up during Year 1 (winter of 2010/2011) and the eight remaining during Year 2 (winter of 2011/2012). With the data from the eight sites used in Year 1, we were able to compare the nesting over 2 years without any site effect and with the data from Year 2 over the 16 sites we were able to compare old and new nesting structures without inter-annual climate fluctuations.

\section{Nesting activity monitoring}

\section{Nesting activity in square soils}

To sample soil-nesting bees, a net cage of $0.36 \times 0.61 \mathrm{~m}$ was placed over a corner of each square for a $45 \mathrm{~min}$ period on a monthly basis from March to September in 2012 and 2013. Since the activity of bee species depends on temperature and day period (e.g. Corbet et al. 1993; Stone et al. 1999; Gottlieb et al. 2005), alternate morning or afternoon samplings were performed only during periods of good weather for foraging activity (maximum temperature $\geq 15^{\circ} \mathrm{C}$, sky sunny or with scattered clouds only, and wind speed $\leq 15 \mathrm{~km} / \mathrm{h}$; Westphal et al. 2008). The corners of the soil squares for net cage placement were randomly chosen at the beginning of the season for each square, and then sampled repeatedly without changes throughout the season. The corners were different in 2012 and in 2013. Bees were captured either in the cage, trying to get out of their nest, or nearby the outside of the cage with a net, when trying to come back into their nest. In the winter 2012, we collected a composite sample of $100 \mathrm{~g}$ of soil representative of the soil volume in each square and the granulometric composition of these samples was analyzed using standard methodology (National Soil Analysis Laboratory, INRA Arras). The percentages of clay, silt and sand on a weight basis were used to locate the soil of each square into the discrete categories of a soil texture triangle (U. S. Department of Agriculture 1951). We used R package plotrix to represent the distribution of soil squares in the texture triangle (Lemon 2006; see Supplementary Methods 1).

\section{Nesting activity in bee hotels}

To make sure that bees were in diapause, we took out an eighth of each type of hotel nesting substrate in each compartment of each hotel at each site after the first winter frost. For the stems, we divided the surface of each compartment in eight parts of $0.2 \times 0.23 \mathrm{~m}$ and took out the elements of one of them (chosen randomly) each winter using a custom-made metallic frame that we pushed amidst the stems. For the logs, we first counted the total number of holes in the logs of each species and then took out logs containing about one eighth of this total number of holes. Each sample of log or stem was put into a net cage of $0.36 \times 0.36 \times 0.61 \mathrm{~m}$ (Bioquip, CA, USA). These cages were placed under a screen tunnel so that bees could 
emerge in the cages all year long. Bees that emerged were collected from the cages on a weekly basis from March to September. Each emergence cage contained logs or stems removed from a single compartment of a hotel. After the removal of each log or stem sample in a compartment, we replaced it with logs or stems of the same species. For each species of material in each compartment, bee occurrence was 1 if there was at least one individual of the bee species considered that emerged from the material, and 0 otherwise, meaning the absence of bee. Abundance was the number of specimens of the bee species considered that emerged from the sample of material and we calculated an emergence rate corresponding to the ratio between the number of emerged bees and the number of holes in the logs or stems.

All the specimens of bee which were collected from the soil squares or the emergence cages were frozen for later processing. Individuals were then pinned, labeled, identified to genus, and sent for identification to species to the respective authority for each genus (see Acknowledgements). All voucher specimens are now deposited in the bee collection of INRA Avignon. For the taxonomy, we followed the nomenclature of Kuhlmann et al. (2013).

\section{Data analyses}

As human-made nesting structures were put in place over 2 years, we conducted diachronic (relating to the changes in the data base that happen over the 2 years) and synchronic (relating to differences between two data base obtained the same year) analyses of the species occurrence and abundance data. First, we analyzed the bees that emerged from the nesting elements of the hotels built in Year 1 in the 2 years that followed their set-up (2012 and 2013; diachronic approach). The same sampling schedule was used for the soil squares set-up in Year 1. This first approach was used to evaluate the colonization pattern over the two seasons in the same structures. Second, we investigated the influence of the age of the nesting materials that was put in place in Year 1 or Year 2 by scoring the emergence that took place over 2013 in all sites (synchronic approach). Combining the two approaches enabled us to test if the age of a nesting structure had a positive or negative influence on its colonization by bees, or if the colonization pattern was more an effect of a particular season. As the data were zero inflated, in subsequent analyses, linear mixed-effects models were used with $o c$ currence (0-1 binary data) and abundance (counts; zero excluded) as dependent variables, while year of sampling or year of construction was the main fixed effect factor. As all sites were different and so were the hotels and composition of the soil squares, we added site, soil square and texture of soil for the analyses of soil squares recordings, and site, bee hotel and material species as random effect factors for the analyses of emergence data from bee hotels. In the analyses of emergence data from bee hotels, we separated bees into three groups (Osmia cornuta (Latreill), $O$. bicornis(Linné) and 'other species'), because $O$. cornuta and $O$. bicornis made over $87 \%$ of the emerging specimens and we analyzed the data separately for each of the three groups.

We also performed linear mixed-effects models to test the effect of either the types of logs or stems in the hotels or the soil texture in the squares on bee species richness for soil squares and emergence rate for bee hotels (dependent variables). Random effect factors were the year of construction and year of sampling combination, and site. Posthoc Tukey tests were done on bee species richness for soil squares and emergence rate for bee hotels to estimate the differences among soil texture classes for the soil squares and logs and hollow stems and pithy stems in bee hotels.

All models were run using lme4 (Bates et al. 2011) and nlme (Pinheiro et al. 2010) packages in $\mathrm{R}$ version 3.2.2 ( $\mathrm{R}$ Core Team 2015). Post-hoc Tukey tests were computed using multcomp package in $\mathrm{R}$ (Hothorn et al. 2008). For the diachronic and synchronic analyses, we used a threefold Bonferroni correction for all models on the three groups of species (Rice 1989).

For the analyses, we took 14 (87.5\% of the total number of studied sites) and $15(93.75 \%)$ sites into account for soil squares and bee hotels, respectively, because all logs and stems had been stolen from the bee hotels on one site and the square soils of two sites were not built soon enough to take them into account.

\section{Results}

First of all, we collected bees at all 16 sites of our study on both soil squares and bee hotels. Furthermore, our dataset is a subsample because we only sampled at random $1 / 4$ th of each soil square and 1/8th of the total number of cavities of each type of nesting substrate in each compartment at each site. So, by extrapolation we could expect to have four times as many bees that nested in the soil squares (i.e. 232) and eight times as many bees that emerged from the hotels (i.e. 3102), that is about 1,000 and 25,000 bees, respectively.

\section{Wild bee fauna in the nesting structures}

\section{Soil squares}

Over the 2 years of sampling, we collected 232 specimens (97 in 2012 and 135 in 2013) belonging to 37 species (23 in 2012 and 31 in 2013) in the soil squares (Table 1). An average of 5.14 bee specimens per site were collected in 
Table 1 List of the species collected in the human-made nesting structures

\begin{tabular}{|c|c|c|c|}
\hline \multicolumn{4}{|l|}{ Emergence from bee hotel } \\
\hline Taxon & Family & Number of specimens in 2012 & Number of specimens in 2013 \\
\hline Anthidium florentinum (Fabricius) & Megachilidae & 12 & 0 \\
\hline Chelostoma florisomne (Linnaeus) & Megachilidae & 11 & 65 \\
\hline Heriades crenulatus Nylander & Megachilidae & 15 & 0 \\
\hline Heriades truncorum (Linnaeus) & Megachilidae & 122 & 21 \\
\hline Hoplitis adunca (Panzer) & Apidae & 2 & 5 \\
\hline Hylaeus communis Nylander & Colletidae & 8 & 1 \\
\hline Hylaeus incongruus Förster & Colletidae & 1 & 0 \\
\hline Megachile centuncularis (Linnaeus) & Megachilidae & 5 & 0 \\
\hline Megachile rotundata (Fabricius) & Megachilidae & 1 & 0 \\
\hline Megachile sculpturalis Smith & Megachilidae & 0 & 16 \\
\hline Megachile versicolor Smith & Megachilidae & 0 & 12 \\
\hline Osmia bicornis (Linnaeus) & Megachilidae & 298 & 535 \\
\hline Osmia brevicornis (Fabricius) & Megachilidae & 0 & 3 \\
\hline Osmia caerulescens (Linnaeus) & Megachilidae & 54 & 9 \\
\hline Osmia cornuta (Latreille) & Megachilidae & 426 & 1450 \\
\hline Osmia melanogaster Spinola & Megachilidae & 1 & 0 \\
\hline Osmia submicans Morawitz & Megachilidae & 12 & 4 \\
\hline Osmia tricornis Latreille & Megachilidae & 1 & 0 \\
\hline Stelis breviuscula Nylander (C) & Megachilidae & 0 & 1 \\
\hline Stelis minuta Lepeletier and Audinet-Serville (C) & Megachilidae & 8 & 0 \\
\hline Xylocopa violacea (Linnaeus) & Apidae & 1 & 2 \\
\hline Total & & 978 & 2124 \\
\hline Total & & 3102 & \\
\hline
\end{tabular}

Captures in soil squares

\begin{tabular}{|c|c|c|c|}
\hline Taxon & Family & Number of specimens in 2012 & Number of specimens in 2013 \\
\hline Andrena dorsata (Kirby) & Andrenidae & 1 & 0 \\
\hline Andrena flavipes Panzer & Andrenidae & 0 & 1 \\
\hline Andrena florea Fabricius & Andrenidae & 0 & 1 \\
\hline Andrena gravida Imhoff & Andrenidae & 0 & 1 \\
\hline Andrena minutula (Kirby) & Andrenidae & 1 & 3 \\
\hline Andrena minutuloides Perkins & Andrenidae & 2 & 1 \\
\hline Andrena simontornyella Noskiewicz & Andrenidae & 1 & 2 \\
\hline Andrena viridescens Viereck & Andrenidae & 0 & 1 \\
\hline Halictus subauratus (Rossi) & Halictidae & 14 & 31 \\
\hline Halictus tumulorum (Linnaeus) & Halictidae & 0 & 2 \\
\hline Hoplitis adunca (Panzer) & Apidae & 0 & 1 \\
\hline Hoplitis ravouxi (Pérez) & Apidae & 0 & 1 \\
\hline Lasioglossum fulvicorne (Kirby) & Halictidae & 1 & 0 \\
\hline Lasioglossum griseolum (Morawitz) & Halictidae & 0 & 2 \\
\hline Lasioglossum laticeps (Schenck) & Halictidae & 1 & 1 \\
\hline Lasioglossum leucozonium (Schrank) & Halictidae & 1 & 2 \\
\hline Lasioglossum malachurum (Kirby) & Halictidae & 3 & 1 \\
\hline Lasioglossum mesosclerum (Pérez) & Halictidae & 0 & 1 \\
\hline Lasioglossum minutissimum (Kirby) & Halictidae & 5 & 12 \\
\hline Lasioglossum morio (Fabricius) & Halictidae & 12 & 24 \\
\hline Lasioglossum pallens (Brullé) & Halictidae & 0 & 1 \\
\hline
\end{tabular}


Table 1 continued

\begin{tabular}{|c|c|c|c|}
\hline \multicolumn{4}{|l|}{ Captures in soil squares } \\
\hline Taxon & Family & Number of specimens in 2012 & Number of specimens in 2013 \\
\hline Lasioglossum pauxillum (Schenck) & Halictidae & 24 & 9 \\
\hline Lasioglossum politum (Schenck) & Halictidae & 6 & 15 \\
\hline Lasioglossum punctatissimum (Schenck) & Halictidae & 0 & 3 \\
\hline Lasioglossum pygmaeum (Schenck) & Halictidae & 3 & 1 \\
\hline Lasioglossum semilucens (Alfken) & Halictidae & 1 & 4 \\
\hline Lasioglossum villosulum (Kirby) & Halictidae & 13 & 6 \\
\hline Lasioglossum zonulum (Smith) & Halictidae & 1 & 0 \\
\hline Megachile pilidens Alfken & Megachilidae & 0 & 2 \\
\hline Nomada atroscutellaris Strand (C) & Apidae & 0 & 1 \\
\hline Nomada bifasciata Olivier (C) & Apidae & 1 & 0 \\
\hline Nomada flavoguttata (Kirby) (C) & Apidae & 2 & 1 \\
\hline Osmia caerulescens (Linnaeus) & Megachilidae & 0 & 2 \\
\hline Osmia submicans Morawitz & Megachilidae & 0 & 2 \\
\hline Sphecodes croaticus Meyer (C) & Halictidae & 1 & 0 \\
\hline Sphecodes ephippius (Linné) (C) & Halictidae & 1 & 0 \\
\hline Sphecodes longulus Hagens (C) & Halictidae & 2 & 0 \\
\hline Total & & 97 & 135 \\
\hline Total & & 232 & \\
\hline
\end{tabular}

(C) Cleptoparasitic bee species

The species collected in both soil squares and bee hotels is in bolt

2012 (with a minimum of 0 and a maximum of 20) and 9.64 in 2013 (with a minimum of 1 and a maximum of 38). The most abundant species was Halictus subauratus (Rossi; $19.4 \%$ of the total number of specimens), which is a non-solitary bee species, which is also the case for the three next most abundant species (Lasioglossum. morio (Fabricius; $15.5 \%$ ), L. pauxillum (Schenck; $14.2 \%$ ) and L. politum (Schenck; 9.1\%)). Six species were cleptoparasites (Apidea: Nomada atroscutellaris Strand, N. bifasciata Olivier, N. flavoguttata (Kirby) and Halictidae: Sphecodes croaticus Meyer, S. ephippius (Linné), and S. longulus Hagens), which represents $16.2 \%$ of the total number of species. We recorded 15 species as singletons that is $40 \%$ of the total number of species.

\section{Bee hotels}

We collected 3,102 specimens (978 in 2012 and 2,124 in 2013) belonging to 21 species (18 in 2012 and 14 in 2013) over the 2 years in the bee hotels (Table 1). An average of 122.25 bee specimens were collected per site in 2012 (with a minimum of 34 and a maximum of 191) and 132.75 in 2013 (with a minimum of 1 and a maximum of 410). The most abundant species were Osmia cornuta $(60 \%$ of the total number of specimens), and O. bicornis (27\%), which are both gregarious species. They were collected on all 16 sites. Two species were cleptoparasites (Megachilidae: Stelis breviuscula Nylander and S. minuta Lepeletier and Audinet-Serville), which represents $9.5 \%$ of the total number of species. We recorded only five species as singletons, i.e. $24 \%$ of the species list. The first emergence was recorded on the 20th of March in 2012 and the 13th of March in 2013 and the last one on the 24th of July in 2012 and on the 12th of August in 2013. The emergences of $O$. cornuta were recorded between the 20th of March and the 26th of June in 2012 and between the 13th of March and the 17th of May in 2013 and between the 24th of March and the 3rd of July in 2012 and between the 13th of March and the 17th of May in 2013 for O. bicornis.

\section{Evolution of colonization over time (diachronic analyses)}

\section{Soil squares}

In the soil squares installed in Year 1, both the occurrence and abundance of wild bees remained similar over the 2 years of sampling (Table 2; Fig. 2a, b). 
Table 2 Pairwise comparisons of the occurrence frequencies and abundance of bee groups during the year of sampling or the year of structure installation

\begin{tabular}{|c|c|c|c|c|c|c|}
\hline Model & Dependent variable & Nesting site type & Bee group & Estimate \pm SE & z-value & $p$ \\
\hline \multirow{8}{*}{$\begin{array}{l}\text { Diachronic analyses: } 2012 \text { vs } 2013 \\
\text { samples }\end{array}$} & \multirow[t]{4}{*}{ Occurrence frequency } & \multirow[t]{3}{*}{ Bee hotels } & Other species & $-1.67 \pm 0.35$ & -4.73 & $<0.001 *$ \\
\hline & & & Osmia bicornis & $-1.02 \pm 0.31$ & -3.26 & $0.0011 *$ \\
\hline & & & Osmia cornuta & $1.31 \pm 0.32$ & 4.15 & $<0.001 *$ \\
\hline & & Soil squares & & $0.57 \pm 0.38$ & 1.52 & 0.13 \\
\hline & \multirow[t]{4}{*}{ Abundance } & \multirow[t]{3}{*}{ Bee hotels } & Other species & $0.01 \pm 0.26$ & 0.04 & 0.97 \\
\hline & & & O. bicornis & $0.65 \pm 0.26$ & 2.45 & 0.037 \\
\hline & & & O. cornuta & $0.45 \pm 0.2$ & 2.25 & 0.032 \\
\hline & & Soil squares & & $0.12 \pm 0.11$ & 1.16 & 0.26 \\
\hline \multirow{8}{*}{$\begin{array}{l}\text { Synchronic analyses: Installation in } \\
2010 / 2011 \text { vs } 2011 / 2012\end{array}$} & \multirow[t]{4}{*}{ Occurrence frequency } & \multirow[t]{3}{*}{ Bee hotels } & Other species & $0.62 \pm 0.52$ & 1.2 & 0.23 \\
\hline & & & O. bicornis & $-5.1 \pm 2.9$ & -1.76 & 0.078 \\
\hline & & & O. cornuta & $-1.61 \pm 0.47$ & -3.41 & $<0.001 *$ \\
\hline & & Soil squares & & $-0.5 \pm 0.7$ & -0.72 & 0.47 \\
\hline & \multirow[t]{4}{*}{ Abundance } & \multirow[t]{3}{*}{ Bee hotels } & Other species & $0.075 \pm 0.39$ & 0.19 & 0.85 \\
\hline & & & O. bicornis & $-0.73 \pm 0.58$ & -1.26 & 0.24 \\
\hline & & & O. cornuta & $-1.13 \pm 0.38$ & -2.96 & $0.012 *$ \\
\hline & & Soil squares & & $-0.23 \pm 0.14$ & -1.69 & 0.12 \\
\hline
\end{tabular}

Significance was calculated after the Bonferroni correction (i.e., $p \times 3$ ) and is marked with an * when $p<0.016$ (See Figs. 2 and 3 for graphical representations)

Fig. 2 Changes over time of the bee captures in soil squares over two consecutive seasons after their installation in the winter of 2010/2011 (a and b) and effect of the age of the soil squares on the bee captures recorded in 2013 (c and d). The symbol and the horizontal bar above each pair of columns indicate the significance of the difference between these years (NS: $p>0.05$. See Table 2 for detailed statistics)
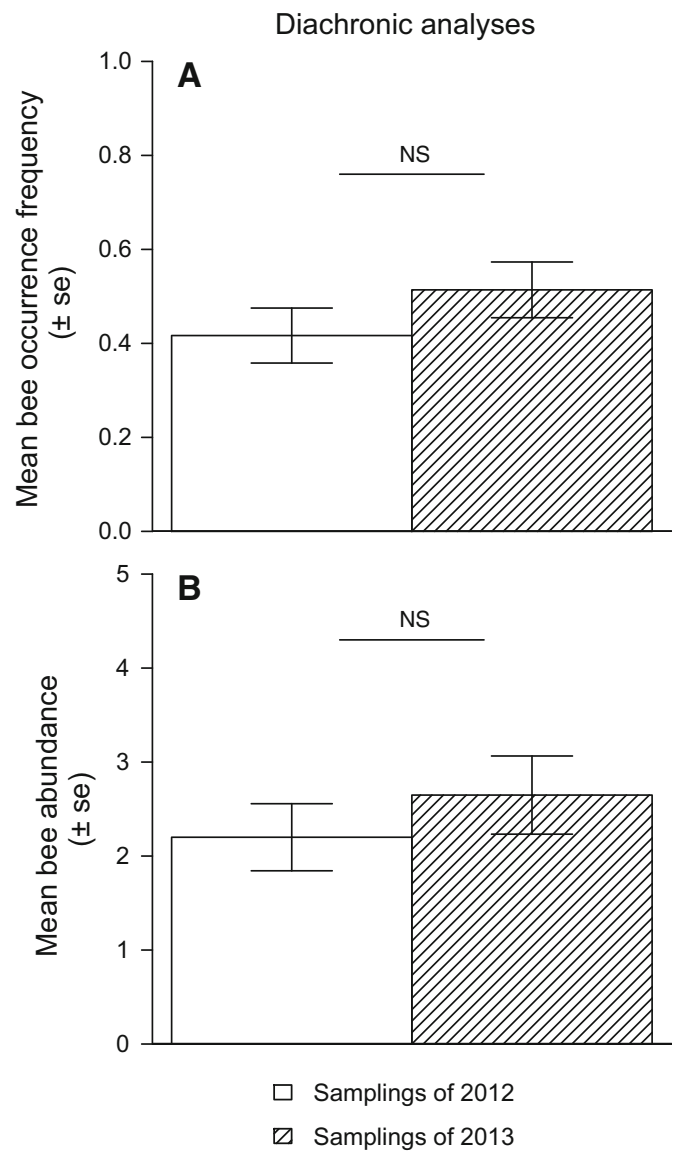

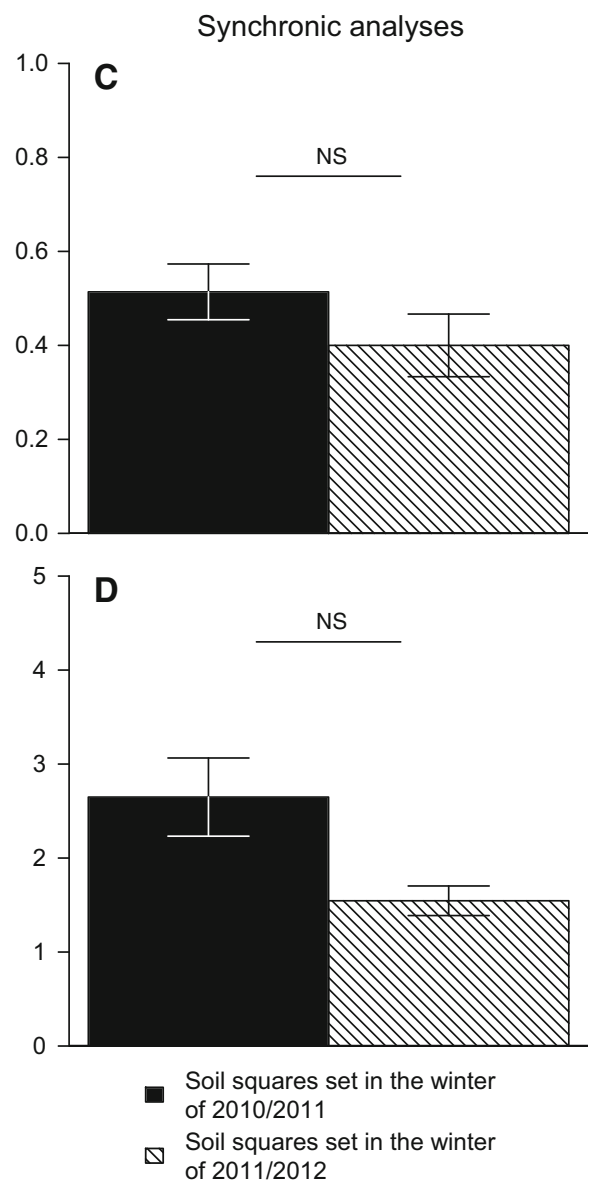


Fig. 3 Changes over time of the bee captures in bee hotels over two consecutive seasons after their installation in the winter of 2010/2011 (a and b) and effect of the age of the material in bee hotels on the bee captures recorded in 2013 (c and d). The symbol and the horizontal bar above each pair of columns indicate the significance of the difference between the years (NS: $p>0.05 ; *: p \leq 0.05$; $* *: p \leq 0.01 ; * * *: p \leq 0.001$. See Table 2 for detailed statistics)
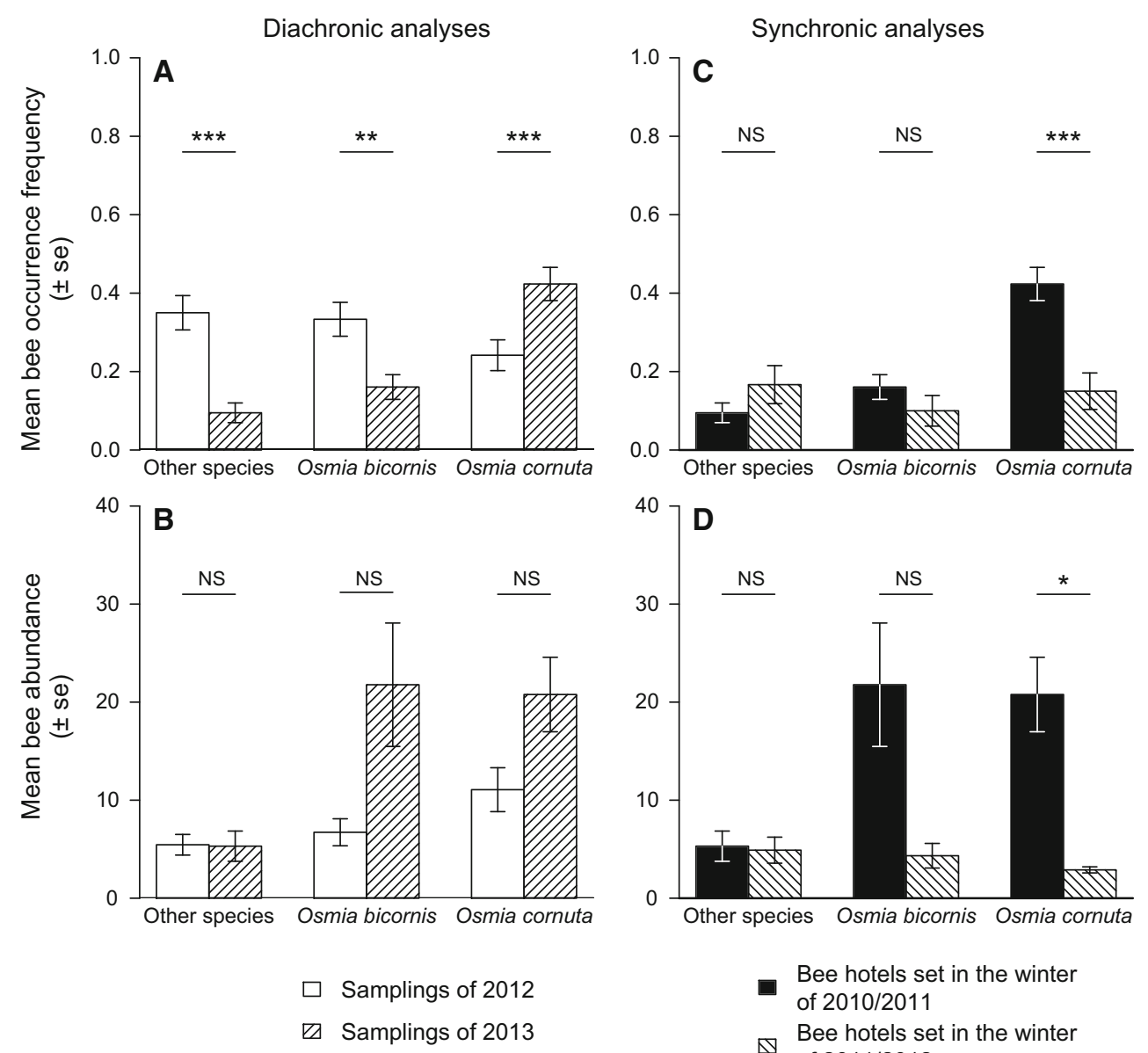

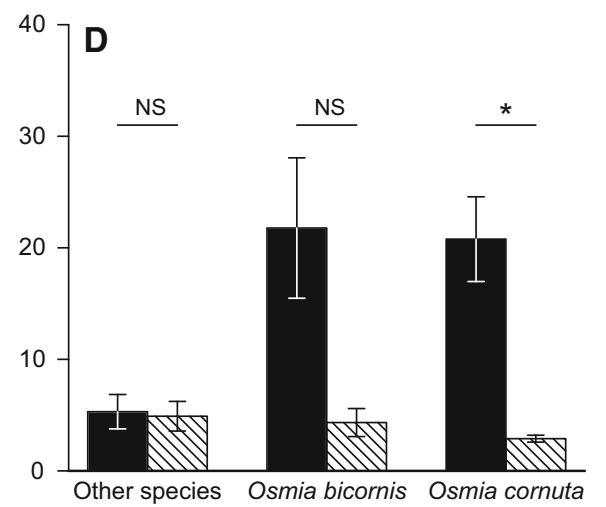

Bee hotels set in the winter of 2010/2011

$\checkmark$ Bee hotels set in the winter of $2011 / 2012$
Bee hotels

In the bee hotels installed in Year 1, the occurrence of each of the three groups was different between the first and second year. Osmia bicornis and 'other species' were significantly less frequent in 2013 than in 2012, but the opposite was true for $O$. cornuta (Table 2; Fig. 3a). The abundance of the three groups of species was similar over the 2 years (Table 2; Figs. 3b).

\section{Influence of the age of nesting structures (synchronic analyses)}

Soil squares

In 2013, neither the occurrence nor the abundance of wild bees was different between the squares built up in Year 1 and those built in Year 2 (i.e., 1-year old soil squares compared to new ones; Table 2; Fig. 2c, d).
Bee hotels

Neither the occurrence nor the abundance of both 'other species' and $O$. bicornis were different between the hotels installed in Year 1 and those installed in Year 2 (Figs. 3a, d). However, both the occurrence and the abundance of $O$. cornuta were lower in the 1-year old hotels than in the new ones (Table 2; Figs. 3c, d).

\section{Effect of nesting substrates}

Soil squares

The soils of our 126 squares (corresponding to 9 squares on each of the 14 sites of the study) fell into six categories in the triangle of soil texture (two clay, three clay-loam, 32 loam, 22 loamy-sand, nine sandy-clay-loam, and 58 sandyloam: see Supplementary Methods 1). Soil texture did not affect the species richness nor on the abundance $\left(\mathrm{F}_{4,246}=1.49, p=0.2\right.$ and $\left.\mathrm{F}_{4,246}=0.62, p=0.64\right)$. 


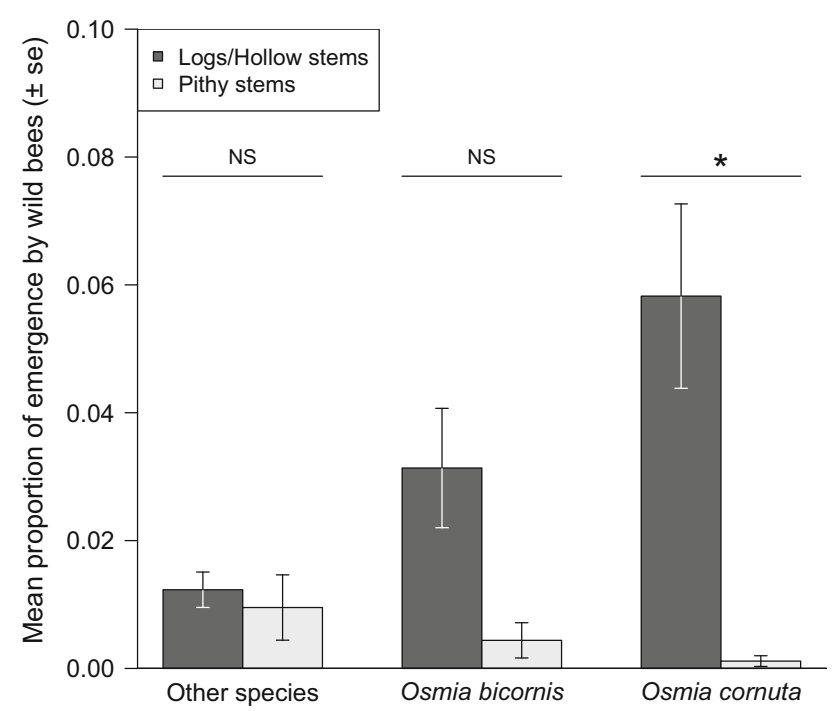

Fig. 4 Mean proportion of emergence rate of wild bees in logs and hollow stems compared to pithy stems. The symbol and the horizontal bar above each pair of columns indicate the significance of the difference between the years (NS: $p>0.05 ; *: p \leq 0.05$ )

\section{Bee hotels}

Both $O$. bicornis and $O$. cornuta nested in holes in logs and hollow stems as well as in pithy stems. The emergence rates of $O$. bicornis and 'other species' were similar in the two categories of substrate, whereas the emergence rate of $O$. cornuta was higher in logs or hollow stems than in pithy stems (Fig. 4). Within each of the two categories of substrate, the emergence rates of $O$. cornuta and of 'other species' were similar among the holes in the eight species of logs and the three species of hollow stems $\left(\mathrm{F}_{10,191}=0.66, p=0.76\right.$ and $\mathrm{F}_{10,191}=0.97, p=0.47$ for $O$. cornuta and 'other species', respectively). This was also the case among the four species of pithy stems $\left(\mathrm{F}_{3,50}=0.84, p=0.48\right.$ and $\mathrm{F}_{3,50}=0.6, p=0.62$ for $O$. cornuta and 'other species', respectively). However, the substrate species had a significant effect on the emergence rate of $O$. bicornis, for both groups of substrates $\left(\mathrm{F}_{10,191}=2.61, p=0.0054\right.$ for logs and hollow stems and $\mathrm{F}_{3,50}=6.08, p=0.0013$ for pithy stems). Indeed, this species nested more in the holes of Acer sp. logs and in the Catalpa sp. pithy stems than in those of any other log or stem species (Fig. 5a, b).

\section{Discussion}

We evaluated the colonization of human-made nesting structures by wild bees at 16 sites and over one or two consecutive years. There was no effect of the year of sampling or the year of installation of the soil squares on the bee occurrence frequency or their abundance. In the bee hotels, the pattern of colonization of Osmia bicornis and the 'other species' were more affected by inter-annual fluctuations than by colonization history. The opposite was observed for $O$. cornuta. Soil texture did not influence the nesting of wild bees in the soil squares. Yet, in the hotels, $O$. bicornis nested more in Acer sp. logs or in Catalpa sp. stems than in any other log or stem species provided to them.

\section{Use of human-made nesting structures in an urban environment}

Over 2 years of sampling in the human-made nesting structures, we collected 37 soil-nesting bee species in the squares and 21 above-ground nesting species in the hotels, which represents $23 \%$ of the 248 wild bee species recorded in the 16 urban and periurban sites in the area (Fortel 2014). Intensive sampling of bees usually leads to a low number of singletons because the numbers of bee specimens and that of singletons are negatively correlated (Williams et al. 2001). In the samples from bee hotels, we recorded only five species as singletons, i.e., $24 \%$ of the species list, which is similar to the $19 \%$ recorded in another study with the extensive sampling of the wild bee fauna in the area with pan trap and net captures ( $\chi^{2}=0.064$, df $=1, p=0.799$; Fortel 2014). This suggests that the sampling of $1 / 8$ th of the nesting material for each type of nesting substrate plant species, at each site and for each year was an intensive strategy. For the soil squares, on the other hand, we sampled bees for only 45 min on a monthly basis, and we recorded 15 species as singletons, that is $40 \%$ of the total number of species, which is different from the proportion of singletons in the overall sampling $\left(\chi^{2}=7.59, d f=1, p=0.0059\right)$ and indicates a much less intensive sampling effort. We recorded only six species of parasitic bees in the soil squares and two in the hotels, that is $15 \%$ of the 46 parasitic species known in the area (Fortel 2014). Although the total of 58 species recorded in the human-made nesting structures is low compared to the regional richness of 248 species, we collected two species in the hotels that were not recorded using either pan-traps or insect net over the 2 years of sampling (one specimen of Osmia tricornis Latreille and 16 of Megachile sculpturalis Smith). Osmia tricornis is a solitary megachilid species from the mediterranean region (Leclercq 2001), and its presence confirms the Mediterranean influence in the area. Megachile sculpturalis, also known as the 'giant resin bee', is an exotic species introduced from central Asia that nests in pre-existing holes in logs or stems and was first recorded in France nearby Marseille along the Mediterranean shore in 2008 (Vereecken and Barbier 2009). Interestingly, this species also arrived in the United States in 1997 and has since spread quickly over a wide area (Mangum and Sumner 2003). It is now considered to be an invasive species in North America, 
A

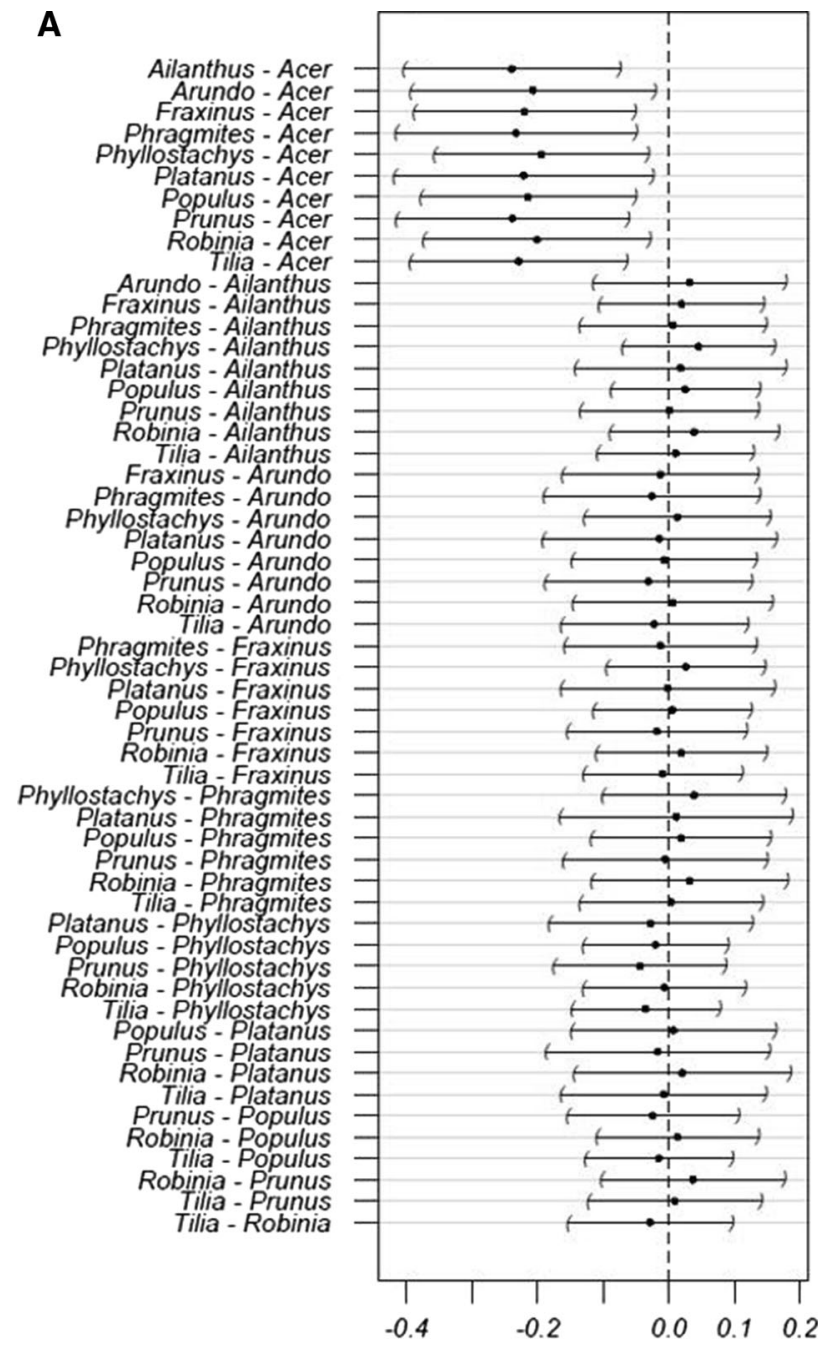

B

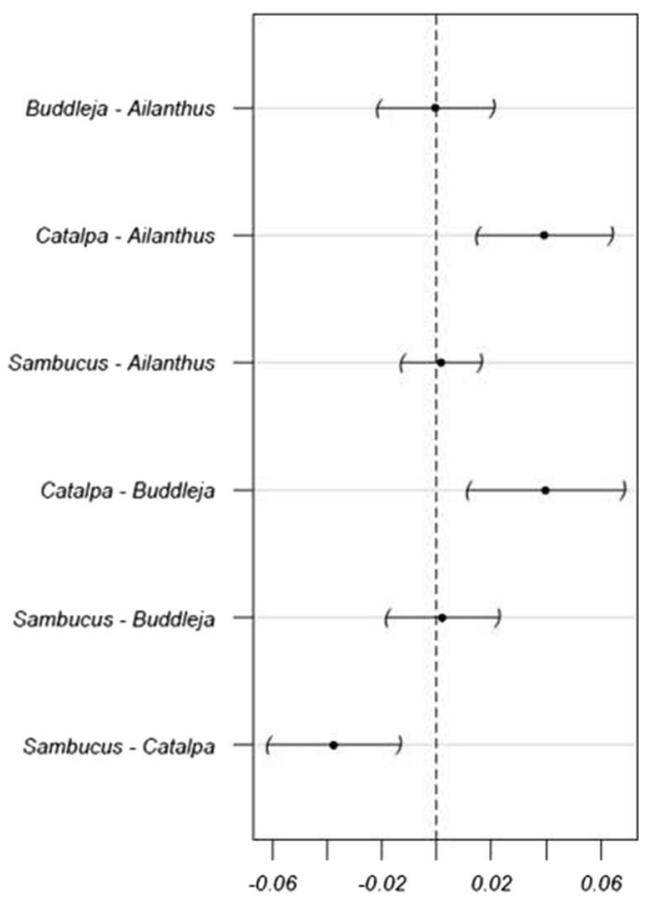

Fig. 5 Pairwise comparisons of the emergence rate of Osmia bicornis among holes in species of logs and hollow stems (a) and among species of pithy stems (b). There is a significant difference in preference between species if the $95 \%$ confidence interval of the difference in means (horizontal line) does not include the null value

McCorquodale 1989; Potts and Willmer 1997). Females that emerged the previous season may learn the position and patch quality of their natal nest and return to that area (Potts and Willmer 1997). In the hotels, the occupation rate of $O$. bicornis was lower in 2013 than in 2012, but we collected as many specimens of $O$. bicornis in 2012 and in 2013. This means that $O$. bicornis was less frequent in 2013 than in 2012 samples, but it was as abundant. Osmia bicornis has a gregarious nesting behavior (Torchio et al. 1987; Krunić et al. 1995), and is philopatric (Neumann and Seidelmann 2006), i.e., the offspring prefer to nest in proximity to the parental nest (Shields 1982). Philopatry is probably an important factor in maintaining spatial stability of the nest aggregations of gregarious species in subsequent years (Polidori et al. 2006). Also, the presence of other individuals, or their nests, may provide a visual stimulus for further nesting at a given site by social facilitation
Bees spend a lot of time and energy searching for suitable nesting sites, so any behavior that makes this process more efficient should be selected for (Brockmann 1980; 
(Rubink 1978). For solitary bees which nest gregariously, the nest recognition appears to be dictated by involving both visual and olfactory cues (Anzenberger 1986; Raw 1992; Guedot et al. 2006). For example, Pitts-Singer (2007) tested the attraction of three species, Osmia lignaria Say, Megachile rotundata (Fabricius), and M. pugnata Say, to various components associated with their old nest cavities, or chemical extracts of these components. Female bees of these species are known to nest in or near old nest cavities, implying that remnant nest components are important cues for bees looking for nest cavities. She showed that female bees were attracted to components that may provide species-specific cues or indicate conspecific nesting activity (Pitts-Singer 2007). However, the use of odor cues from old nests for nest establishment should not be confused with the phenomenon of how these bees also will also build nests next to conspecifics once a few nests are initiated in a nesting board (Pitts-Singer 2007). In some cases, philopatry is associated with gregariouness (Michener et al. 1958), but, in this study, the population of other species had the same pattern of change as that of $O$. bicornis. For $O$. cornuta, the age of bee hotel nesting materials had an effect on the colonization, with 2-year old nesting structures being more colonized than 1-year old ones. The species other than $O$. bicornis and O. cornuta were less frequent, but as abundant in the hotels built in the winter of 2010/2011 in the samples that emerged in 2013 than in those of 2012. The colonization of these species was more affected by interannual variations than by the age of the nesting structure. Another factor that could explain the observed tendencies is parasitism, which we did not study, although we captured several parasitic bee and non-bee species. Bee hotels facilitate the increase of parasites and predators caused by the unnaturally high nest densities and the fact that nesting site entrances are set up in two-dimensions rather than in the more three dimensional arrangement found in nature (e.g. erect plant stems, decaying logs; Wcislo 1996; MacIvor and Packer 2015). Encouraging different bee species to co-aggregate in a bee hotel might increase opportunity for parasites to attack related species (Macivor and Salehi 2014).

Although the four most abundant species in the soil squares were almost all non-solitary (Danforth et al. 2003; Oertli et al. 2005), no clear pattern of change was observed either in the occurrence or in the abundance in the diachronic and synchronic analyses. This may be a result of the low sampling intensity used to collect bees in the soil squares.

\section{Substrate selection}

In our study, the texture of soil had no influence on bee species richness. This result is not fully in agreement with those of Cane (1991) who concluded that bee species could be separated in two groups depending on their soil preference. One group nested preferentially in sands, loamy sands and more rarely in sandy loams, while the other group nested mainly in loams (sandy-, silt-, sandy clay- or clay-; Cane 1991). Also, larger species tended to nest in soils with greater clay content (Cane 1991). It is also noteworthy that, for lack of time and because we could not find any reference indicating that bees might actually nest in our soil squares, there are several characteristics that we did not take into account in our study such as the availability of bare soil in the landscape, the level of compaction of the soil in our squares (hardness), and its slope and orientation in regards to sunshine, both of which are also important for nest site selection of ground-nesting bees (Wuellner 1999; Potts et al. 2005).

In the hotels, O. bicornis and $O$. cornuta nested in all of the available substrates. These two species show great flexibility in the nesting substrates that they use, especially $O$. bicornis (Coudrain et al. 2015). Furthermore, $O$. bicornis was the only bee species that displayed nesting substrate preferences (for stems of Catalpa sp. and logs of Acer sp.). Catalpa sp. is a species with pithy stems, so bees have to dig their own cavities to use them.

\section{Management implications and conclusions}

That a diverse wild bee fauna (i.e., 57 species, which is $19.5 \%$ of the total number of species found in this area (Fortel et al. 2014)) used our artificial nesting structures is an important result that highlights the usefulness of these structures to manage urban areas to encourage wild bees. Yet, as we discussed, it further studies would be needed to monitor the changes in colonization and bee community structure over more than 2 years to evaluate the evolution of parasitism in the nesting structures. Much attention in the past has focused upon improving floral resources available for bees and conserving and enhancing floral communities (Potts et al. 2003; Mader et al. 2011; Kirk and Howes 2012). However, to date little effort has focused upon the complementary and critical need for nesting resource provisioning. Proper urban management requires both resources to be available to attract and sustain diverse bee communities and the pollination services they provide. Furthermore, in addition to the direct usefulness of humanmade nesting sites for bees, those structures are also a powerful tool to raise the awareness of urban citizens about biodiversity and ecosystem services.

Acknowledgments We would like to thank Jean Aptel, Quentin Brunet-Dunand, Anne Laure Guirao, Vincent Létoublon, and JeanPaul Vermandère for field assistance. We also thank all the specialists who identified our bee specimens: Holger Dathe for Hylaeus spp., Eric Dufrêne for Nomada spp. and Sphecodes spp., David Genoud for 
Andrena spp., Gerard Le Goff for Megachilidae, Alain Pauly for Halictus and Lasioglossum spp., Erwin Scheuchl for Andrena spp., and Robert Fonfria for all other genera. We are grateful to Charlotte Visage for her great help and skills as coordinator of the Urbanbees project. We thank Hervé Mureau for his identifications of the different varieties of stems and $\operatorname{logs}$ in bee hotels. Finally, we are grateful to the numerous persons who helped in the establishment of the nesting structures and contributed to the project.

Open Access This article is distributed under the terms of the Creative Commons Attribution 4.0 International License (http://crea tivecommons.org/licenses/by/4.0/), which permits unrestricted use, distribution, and reproduction in any medium, provided you give appropriate credit to the original author(s) and the source, provide a link to the Creative Commons license, and indicate if changes were made.

\section{References}

Amiet F, Müller A, Neumeyer R (1999) Apidae 2: Colletes, Dufourea, Hylaeus, Nomia, Nomioides, Rhophitoides, Rophites, Sphecodes, Systropha

Amiet F, Herrmann M, Müller A, Neumeyer R (2004) Apidae 4: Anthidium, Chelostoma, Coelioxys, Dioxys, Heriades, Lithurgus, Megachile, Osmia, Stelis. Centre Suisse de Cartographie de la Faune

Anzenberger G (1986) How do carpenter bees recognize the entrance of their nests? An experimental investigation in a natural habitat. Ethology 71:54-62. doi:10.1111/j.1439-0310.1986.tb00569.x

Banaszak-Cibicka W, Żmihorski M (2012) Wild bees along an urban gradient: winners and losers. J Insect Conserv 16:331-343

Bates D, Maechler M, Bolker B (2011) lme4: linear mixed-effects models using $\mathrm{S} 4$ classes

Brockmann HJ (1980) The control of nest depth in a digger wasp (Sphex ichneumoneus L.). Anim Behav 28:426-445. doi:10. 1016/S0003-3472(80)80051-0

Cane JH (1991) Soils of ground-nesting bees (Hymenoptera: Apoidea): texture, moisture, cell depth and climate. J Kans Entomol Soc 64:406-413

Cane JH (2008) A native ground-nesting bee (Nomia melanderi) sustainably managed to pollinate alfalfa across an intensively agricultural landscape. Apidologie 39:315-323. doi:10.1051/ apido: 2008013

Cane JH, Minckley RL, Kervin LJ et al (2006) Complex responses within a desert bee guild (Hymenoptera: Apiformes) to urban habitat fragmentation. Ecol Appl 16:632-644. doi:10.1890/10510761(2006)016[0632:CRWADB]2.0.CO;2

Corbet SA, Fussell M, Ake R et al (1993) Temperature and the pollinating activity of social bees. Ecol Entomol 18:17-30. doi:10.1111/j.1365-2311.1993.tb01075.x

Coudrain V, Rittiner S, Herzog F et al (2015) Landscape distribution of food and nesting sites affect larval diet and nest size, but not abundance of Osmia bicornis. Insect Sci. doi:10.1111/17447917.12238

Czech B, Krausman PR, Devers PK (2000) Economic associations among causes of species endangerment in the United States. Bioscience 50:593-601. doi:10.1641/0006-3568(2000)050[0593: EAACOS]2.0.CO;2

Danforth BN, Conway L, Ji S (2003) Phylogeny of eusocial Lasioglossum reveals multiple losses of eusociality within a primitively eusocial clade of bees (Hymenoptera; Halictidae). Syst Biol 52:23-36. doi:10.1080/10635150390132687
Fetridge ED, Ascher JS, Langellotto GA (2008) The bee fauna of residential gardens in a suburb of New York city (Hymenoptera: Apoidea). Ann Entomol Soc Am 101:1067-1077

Fliszkiewicz M, Langowska A, Tryjanowski P (2013) Effect of manipulated sex ratio on insemination of the red mason bee Osmia bicornis L. under net cage conditions. J Apic. doi:10. 2478/jas-2013-0018

Fortel L (2014) Ecologie et conservation des abeilles sauvages le long d'un gradient d'urbanisation. Thèse de doctorat, Université d'Avignon et des Pays du Vaucluse

Fortel L, Henry M, Guilbaud L et al (2014) Decreasing abundance, increasing diversity and changing structure of the wild bee community (Hymenoptera: Anthophila) along an urbanization gradient. PLoS ONE 9:e104679. doi:10.1371/journal.pone. 0104679

Frankie GW, Thorp RW, Schindler M et al (2005) Ecological patterns of bees and their host ornamental flowers in two northern California cities. J Kans Entomol Soc 78:227-246. doi:10.2307/ 25086268

Garbuzov M, Ratnieks FLW (2014) Quantifying variation among garden plants in attractiveness to bees and other flower-visiting insects. Funct Ecol 28:364-374. doi:10.1111/1365-2435.12178

Gottlieb D, Keasar T, Shmida A, Motro U (2005) Possible foraging benefits of bimodal daily activity in Proxylocopa olivieri (Lepeletier) (Hymenoptera: Anthophoridae). Environ Entomol 34:417-424. doi:10.1603/0046-225X-34.2.417

Greenleaf SS, Williams NM, Winfree R, Kremen C (2007) Bee foraging ranges and their relationship to body size. Oecologia 153:589-596. doi:10.1007/s00442-007-0752-9

Grundel R, Jean RP, Frohnapple KJ et al (2010) Floral and nesting resources, habitat structure, and fire influence bee distribution across an open-forest gradient. Ecol Appl 20:1678-1692

Guedot C, Pitts-Singer TL, Buckner JS et al (2006) Olfactory cues and nest recognition in the solitary bee Osmia lignaria. Physiol Entomol 31:110-119. doi:10.1111/j.1365-3032.2005.00490.x

Hennig EI, Ghazoul J (2012) Pollinating animals in the urban environment. Urban Ecosyst 15:149-166. doi:10.1007/s11252011-0202-7

Hothorn T, Bretz F, Westfall P (2008) Simultaneous inference in general parametric models. Biom J 50:346-363

InfoClimat (2011) InfoClimat. http://www.infoclimat.fr/stationsmeteo/climato-moyennes-records.php?staid $=07481 \&$ from $=1981$ $\&$ to $=2010 \&$ redirect $=1$. Accessed 29 Aug 2013

Insee Rhône-Alpes (2013) Insee Rhône-Alpes - Agglo Grand Lyon (ZT9GL). http://www.insee.fr/fr/regions/rhone-alpes/default. asp?page=themes/dossiers_electroniques/tableau_bord/cdra/cdra_ grand_lyon.htm. Accessed 22 Jul 2013

Kim J, Williams N, Kremen C (2006) Effects of cultivation and proximity to natural habitat on ground-nesting native bees in California sunflower fields. J Kans Entomol Soc 79:309-320

Kirk WD, Howes F (2012) Plants for bees: a guide to the plants that benefit the bees of the British Isles. International Bee Research Association, Cardiff

Krombein KV, Wasps T (1967) Trap-nesting wasps and bees: Life histories, nests, and associates. In: Smithsonian Press. Washington, DC, pp 1-570

Krunić M, Pinzauti M, Felicioli A, Stanisavljevic L (1995) Further observations on Osmia cornuta Latr. and O. [Osmia] rufa L. as alternative fruit pollinators, domestication and utilization. Arch Biol Sci Yugosl 47:59-66

Kuhlmann M, et al (2013) Checklist of the western palaearctic bees (Hymenoptera: Apoidea: Anthophila). http://westpalbees.myspe cies.info/. Accessed 10 Sept 2013

Laport RG, Minckley RL (2012) Occupation of active Xylocopa virginica nests by the recently invasive Megachile sculpturalis in 
upstate New York. J Kans Entomol Soc 85:384-386. doi:10. 2317/0022-8567-85.4.384

Leclercq J (2001) Armand Descy fait en 1924 la démonstration expérimentale de la parthénogenèse arrhénotoque chez un hyménoptère solitaire, Osmia tricornis Latreille (Apoidea Megachilidae). Notes Fauniques Gembloux 44:27-31

Lemon J (2006) Plotrix: a package in the red light district of $\mathrm{R}$. R-News 6:8-12

Lonsdorf E, Kremen C, Ricketts T, et al (2009) Modelling pollination services across agricultural landscapes. Ann Bot mcp069. doi: 10.1093/aob/mcp069

MacIvor JS, Packer L (2015) "Bee hotels" as tools for native pollinator conservation: a premature verdict? PLoS ONE 10:e0122126. doi:10.1371/journal.pone.0122126

Macivor JS, Salehi B (2014) Bee species-specific nesting material attracts a generalist parasitoid: implications for co-occurring bees in nest box enhancements. Environ Entomol 43:1027-1033. doi:10.1603/EN13241

Mader E, Shepherd M, Vaughan M et al (2011) Attracting native pollinators-Protecting north America's bees and butterflies. Storey Pub, North Adams

Mangum WA, Sumner S (2003) A survey of the North American range of Megachile (Callomegachile) sculpturalis, an adventive species in North America. J Kans Entomol Soc 76:658-662

Marzluff JM, Ewing K (2001) Restoration of fragmented landscapes for the conservation of birds: a general framework and specific recommendations for urbanizing landscapes. Restor Ecol 9:280-292. doi:10.1046/j.1526-100x.2001.009003280.x

McCorquodale DB (1989) Soil softness, nest initiation and nest sharing in the wasp, Cerceris antipodes (Hymenoptera: Sphecidae). Ecol Entomol 14:191-196. doi:10.1111/j.1365-2311.1989. tb00769.x

McFrederick QS, LeBuhn G (2006) Are urban parks refuges for bumble bees Bombus spp. (Hymenoptera: Apidae)? Biol Conserv 129:372-382

Meekins JF, McCarthy BC (2001) Effect of environmental variation on the invasive success of a nonindigenous forest herb. Ecol Appl 11:1336-1348

Michener CD (2007) The bees of the world, 2nd edn. The Johns Hopkins University Press, Baltimore and London

Michener CD, Lange RB, Bigarella JJ, Salamuni R (1958) Factors influencing the distribution of bees' nests in earth banks. Ecology 39:207-217. doi:10.2307/1931865

Morandin LA, Kremen C (2013) Hedgerow restoration promotes pollinator populations and exports native bees to adjacent fields. Ecol Appl 23:829-839. doi:10.1890/12-1051.1

Müller N, Werner P (2010) Urban biodiversity and the case for implementing the convention on biological diversity in towns and cities. Wiley, Oxford

Müller N, Ignatieva M, Nilon CH et al (2013) Patterns and Trends in Urban Biodiversity and Landscape Design. In: Elmqvist T, Fragkias M, Goodness J et al (eds) Urbanization, biodiversity and ecosystem services: challenges and opportunities. Springer, Netherlands, pp 123-174

Neumann K, Seidelmann K (2006) Microsatellites for the inference of population structures in the Red Mason bee Osmia rufa (Hymenoptera, Megachilidae). Apidologie 37:75-83. doi:10. 1051/apido:2005060

O'Toole C, Raw A (2004) Bees of the world. Facts On File, New York

Oertli S, Mueller A, Dorn S (2005) Ecological and seasonal patterns in the diversity of a species-rich bee assemblage (Hymenoptera: Apoidea: Apiformes). Eur J Entomol 102:53-63

Pinheiro J, Bates D, DebRoy S, et al (2010) NLME: linear and nonlinear mixed effects models
Pitts-Singer TL (2007) Olfactory response of megachilid bees, Osmia lignaria, Megachile rotundata, and $M$. pugnata, to individual cues from old nest cavities. Environ Entomol 36:402-408

Polidori C, Casiraghi M, Lorenzo MD et al (2006) Philopatry, nest choice, and aggregation temporal-spatial change in the digger wasp Cerceris arenaria (Hymenoptera: Crabronidae). J Ethol 24:155-163. doi:10.1007/s10164-005-0176-0

Potts S, Willmer P (1997) Abiotic and biotic factors influencing nestsite selection by Halictus rubicundus, a ground-nesting halictine bee. Ecol Entomol 22:319-328. doi:10.1046/j.1365-2311.1997. 00071.x

Potts SG, Vulliamy B, Dafni A et al (2003) Linking bees and flowers: how do floral communities structure pollinator communities? Ecology 84:2628-2642

Potts SG, Vulliamy B, Roberts S et al (2005) Role of nesting resources in organising diverse bee communities in a Mediterranean landscape. Ecol Entomol 30:78-85. doi:10.1111/j.03076946.2005.00662.x

Pouvreau A (2004) Les insectes pollinisateurs. Delachaux et Niestlé, Paris

R Core Team (2015) R: A language and environment for statistical computing. R Foundation for Statistical Computing, Vienna

Raw A (1992) Solitary bees (Hymenoptera: Megachilidae), restricted to identical resources for nesting, recognized their own nests: an example of genetically determined personal scents? Entomologist 111:79-87

Rezkova K, Žáková M, Žáková Z, Straka J (2011) Analysis of nesting behavior based on daily observation of Andrena vaga (Hymenoptera: Andrenidae). J Insect Behav 25:24-47. doi:10.1007/ s10905-011-9274-8

Rice WR (1989) Analyzing tables of statistical tests. Evolution 43:223-225

Roubik DW (1989) Ecology and natural history of tropical bees. Cambridge University Press, Cambridge

Roulston T, Malfi R (2012) Aggressive eviction of the eastern carpenter bee (Xylocopa virginica (Linnaeus)) from its nest by the giant resin bee (Megachile sculpturalis Smith). J Kans Entomol Soc 85:387-388. doi:10.2317/0022-8567-85.4.387

Rubink WL (1978) The use of edaphic factors as cues for nest-site selection by sand wasps (Hymenoptera: Sphecidae). $\mathrm{PhD}$ thesis, Colorado State University

Sardiñas HS, Kremen C (2014) Evaluating nesting microhabitat for ground-nesting bees using emergence traps. Basic Appl Ecol 15:161-168. doi:10.1016/j.baae.2014.02.004

Scott VL (1994) Phenology and trap selection of three species of Hylaeus (Hymenoptera: Colletidae) in upper Michigan. Gt Lakes Entomol USA 27:39-47

Shields WM (1982) Philopatry, inbreeding, and the evolution of sex. State University of New York, Albany

Steffan-Dewenter I, Leschke K (2003) Effects of habitat management on vegetation and above-ground nesting bees and wasps of orchard meadows in Central Europe. Biodivers Conserv 12:1953-1968. doi:10.1023/A:1024199513365

Stone GN, Gilbert F, Willmer P et al (1999) Windows of opportunity and the temporal structuring of foraging activity in a desert solitary bee. Ecol Entomol 24:208-221. doi:10.1046/j.13652311.1999.00181.x

Torchio PF, Asensio E, Thorp RW (1987) Introduction of the european bee, Osmia cornuta, into California almond orchards (Hymenoptera: Megachilidae). Environ Entomol 16:664-667

U. S. Department of Agriculture (1951) Soil survey manual. U. S. Department of Agriculture

Vereecken NJ, Barbier E (2009) Premières données sur la présence de l'abeille asiatique Megachile (Callomegachile) sculpturalis Smith (Hymenoptera, Megachilidae) en Europe. Osmia 3:4-6 
Wcislo WT (1987) The roles of seasonality, host syncrony, and behaviour in the evolutions and distributions of nest parasites in Hymenoptera (Insecta) with special reference to bees (Apoidea). Biol Rev 62:515-542. doi:10.1111/j.1469-185X.1987.tb01640.x

Wcislo WT (1996) Parasitism rates in relation to nest site in bees and wasps (Hymenoptera: Apoidea). J Insect Behav 9:643-656. doi:10.1007/BF02213885

Westphal C, Bommarco R, Carré G et al (2008) Measuring bee diversity in different European habitats and biogeographical regions. Ecol Monogr 78:653-671

Williams NM, Minckley RL, Silveira FA (2001) Variation in native bee faunas and Its implications for detecting community changes. Conserv Ecol 5:[online] URL: http://www.consecol. org/vol5/iss1/art7/
Wuellner CT (1999) Nest site preference and success in a gregarious, ground-nesting bee Dieunomia triangulifera. Ecol Entomol 24:471-479. doi:10.1046/j.1365-2311.1999.00215.x

Zanette LRS, Martins RP, Ribeiro SP (2005) Effects of urbanization on Neotropical wasp and bee assemblages in a Brazilian metropolis. Landsc Urban Plan 71:105-121. doi:10.1016/j.land urbplan.2004.02.003

Zurbuchen A, Cheesman S, Klaiber J et al (2010a) Long foraging distances impose high costs on offspring production in solitary bees. J Anim Ecol 79:674-681

Zurbuchen A, Landert L, Klaiber J et al (2010b) Maximum foraging ranges in solitary bees: only few individuals have the capability to cover long foraging distances. Biol Conserv 143:669-676 